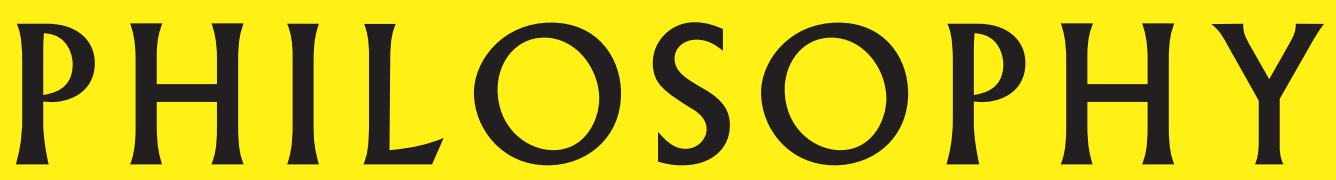

The Journal of the Royal Institute of Philosophy

volume 92 number 360 April 2017

Edited by Anthony O’Hear

Contributions by

AMELIE OKSENBERG RORTY

SINA TALACHIAN

BENCE NANAY

ROBERTO DI CEGLIE

SHANE RYAN

P. M. S. HACKER

FREDRIK NYSETH

ISSN: 0031-8191 


\section{The Royal Institute of Philosophy}

\section{Founded in 1925}

President The Lord Sutherland of Houndwood, KT, FBA, FRSE

Chairman of the Council Professor John Haldane

Hon. Director Professor Anthony O'Hear

Hon. Editor of 'Philosophy' Professor Anthony O'Hear

Secretary Dr James Garvey Treasurer G. A. Philip

International Advisory Board: Simon Blackburn, Cambridge University; Jerry Fodor, Rutgers University; Frank Jackson, Australian National University; Graham Priest, University of Melbourne; John Searle, University of California

Editorial Board of 'Philosophy' Helen Beebee, University of Manchester; Alexander Bird, University of Bristol; N. F. Bunnin, University of Oxford; Stephen Clark, University of Liverpool; Paul Coates, University of Hertfordshire; Ted Honderich, University College London; Kevin Magill, University of Wolverhampton; Alan Millar, University of Sterling; Paul Noordhof, University of York; Barry C. Smith, School of Advanced Study, University of London

Editorial Assistant Adam Ferner

\section{Membership}

The Institute welcomes as members any who are interested in philosophy. There are branches of the Institute in many regional centres, details of which are on the Institute's website. In these branches, and at the London headquarters, an annual programme of lectures is arranged. Members receive copies of Philosophy but not the Supplements (see under Subscriptions below), but these are available to members at a $20 \%$ discount.

The annual subscription is $£ 25.00, \$ 45.00$ in the USA and Canada. For full-time students and those registered as unemployed the subscription is $£ 10.00$ or $\$ 22.00$. Applications should be made to THE SECRETARY, ROYAL INSTITUTE OF PHILOSOPHY, 14 GORDON SQUARE, LONDON, WC1H 0AR or via the Institute's website http://www.royalinstitutephilosophy.org.

\section{Permission}

This journal is registered with the Copyright Clearance Center, 222 Rosewood Drive, Danvers, MA 01923, USA. Organizations in the USA who are registered with the CCC may therefore copy material (beyond the limits permitted by sections 107 and 108 of USA copyright law) subject to payment to the CCC of the per copy fee of $\$ 12.00$. This consent does not extend to multiple copying for promotional or commercial purposes. Code 0031-8191/2015/\$12.00.

Organizations authorized by the Copyright Licensing Agency may also copy material subject to the usual conditions. ISI Tear Sheet Service, 3501 Market Street, Philadelphia, PA 19104, USA, is authorized to supply single copies of separate articles for private use only. For all other use, permission must be sought from Cambridge or the American Branch of Cambridge University Press.

\section{Subscriptions}

Philosophy (ISSN 0031-8191) is published quarterly in January, April, July and October. The well-established RIP Lecture Series and collections of the papers delivered at the annual conference organized by the Royal Institute of Philosophy are published as Supplements to Philosophy and included in the institutional subscription price. Two supplementary volumes are published annually. An institutional subscription to Philosophy includes three issues of Think. The subscription price (excluding VAT) of volume 92 (2017), which includes print and electronic access, is $£ 501.00$ (US $\$ 905.00$ in the USA, Canada and Mexico). The electroniconly price available to institutional subscribers is $f_{4} 431.00$ (US $\$ 767$ in the US, Canada and Mexico). Prices include delivery by air. EU subscribers (outside the UK) who are not registered for VAT should add VAT at their country's rate. VAT registered subscribers should provide their VAT registration number. Orders, which must be accompanied by payment, may be sent to any bookseller or subscription agent or direct to the publisher: Cambridge University Press, Journals Fulfillment Department, UPH, Shaftesbury Road, Cambridge CB2 8BS, UK; or in the USA, Canada and Mexico, Cambridge University Press, Journals Fulfillment Department, Journals Fulfillment Department, 1 Liberty Plaza, Floor 20, New York, NY, 10006, USA. Japanese prices for institutions are available from Kinokuniya Company Ltd, P.O. Box 55, Chitose, Tokyo 156, Japan.

Periodicals postage is paid at New York, NY and at additional mailing offices. POSTMASTER: send address changes in USA, Canada and Mexico to Cambridge University Press, Journals Fulfillment Department, 1 Liberty Plaza, Floor 20, New York, NY, 10006, USA. (C) The Royal Institute of Philosophy 2017

Typeset by Techset Composition Ltd, Salisbury, UK

Printed in the United Kingdom at Bell \& Bain Ltd, Glasgow 